\title{
Synthesis and characterization of magnetic nanoparticles coated with silica through a sol-gel approach
}

\section{(Síntese e caracterização de nanopartículas magnéticas revestidas com sílica através de um processo sol-gel)}

\author{
A. L. Andrade, D. M. Souza, M. C.Pereira, J. D. Fabris, R. Z. Domingues \\ Departamento de Química, Universidade Federal de Minas Gerais, C.P. 702, Belo Horizonte, MG, 31270-901 \\ rosanazd@ufmg.br
}

\begin{abstract}
This paper investigates the influence of reaction medium $\mathrm{pH}$ on silica-coating of magnetite nanoparticles. Magnetite nanoparticles were prepared by means of a reduction-precipitation method using ferric chloride as a starting material, which was partially reduced to ferrous salts by $\mathrm{Na}_{2} \mathrm{SO}_{3}$ before alkalinizing with ammonia. The particles were coated by sol-gel method with either ammonia or $\mathrm{HCl}$ aqueous solutions for either base- or acid-catalyzed hydrolysis, respectively. Powder X-ray diffraction, Fourier-transform infrared, and Zeta Potential were used for the characterization of oxides and of the coated magnetic nanoparticles. The observed difference of $\mathrm{pH}_{\mathrm{IEP}}$ in $\mathrm{KCl}$ solution for pure silica (2.0), magnetite (5.0), and silica-coated magnetite (2.3) samples confirms that the coating process was effective since the charge surface properties of coated magnetic nanoparticles are close to that of pure silica, even though the Fourier-transform infrared spectra did not evidence the formation of Fe-O-Si bonds.
\end{abstract}

Keywords: magnetite, coating, nanoparticles.

\section{Resumo}

Este trabalho aborda a influência do pH do meio de reação, no procedimento de revestimento de nanopartículas magnéticas de magnetita, preparadas por redução-precipitação de cloreto férrico. O material de partida foi parcialmente reduzido a sal ferroso, por reação com $\mathrm{Na}_{2} \mathrm{SO}_{3}$, antes da alcalinização, com amônia. As partículas foram revestidas, pelo método sol-gel, a partir de solução aquosa de amônia ou ácido clorídrico, para promover a hidrólise catalisada por base ou ácido, respectivamente. Os materiais, de óxidos de ferro e de nanopartículas magnéticas revestidas, assim produzidos, foram caracterizados por difração de raios $X$, método do pó, por infravermelho com transformada de Fourier e por potencial zeta para a determinação do pH do ponto isoelétrico $\left(\mathrm{pH}_{I E P}\right)$. A diferença observada do $\mathrm{pH}_{I E P}$ em solução de $\mathrm{KCl}$ para amostras de sílica pura $(2,0)$, magnetita $(5,0)$ e para a magnetita revestida por sílica (2,3) confirma que o processo de revestimento foi efetivo, uma vez que as propriedades de carga de superfície das nanopartículas magnéticas revestidas são próximas às da sílica pura, apesar de o espectro de infravermelho com transformada de Fourier não evidenciar padrões espectrais característicos de ligações $\mathrm{Fe}$-O-Si.

Palavras-chave: magnetita, revestimento, nanopartículas.

\section{INTRODUCTION}

Chemically synthesized magnetic nanoparticles have drawn much attention [1-3] due to the unique magnetic properties associated to their size magnitude and distribution uniformity. Among these particles, magnetite nanoparticles have been widely studied with biomedical applications in view, such as magnetic resonance imaging for clinical diagnosis, magnetic drug targeting, hyperthermia anti-cancer strategy, and enzyme immobilization [4-11].

Magnetite $\left(\mathrm{Fe}_{3} \mathrm{O}_{4}\right)$, a common magnetic iron oxide, has a cubic inverse spinel structure with oxygen forming a FCC closed packing and $\mathrm{Fe}$ cations occupying the interstitial tetrahedral and octahedral sites [12]. The electrons can hop between $\mathrm{Fe}^{2+}$ and $\mathrm{Fe}^{3+}$ ions in octahedral sites even at room temperature, rendering magnetite an important half-metallic material [13]. Due to the anisotropic dipolar attraction, unmodified magnetic nanoparticles of iron oxides tend to aggregate into large clusters and thus lose the specific properties associated with single-domain. In addition, the reactivity of iron oxide particles has been shown to increase greatly as their dimensions are reduced and they may undergo rapid biodegradation when exposed directly to biological systems $[14,15]$. Suitable coating is essential to prevent such limitation [16]. Silica coating of magnetic nanoparticles has become a promising and important approach in the development of magnetic nanoparticles for both fundamental study and technological research. The formation of a silica coating on the surface of iron oxide nanoparticles could help prevent their aggregation in liquid and improve their chemical stability. Another advantage of silica-coating iron oxide nanoparticles is that the silanolterminated surface groups may be modified with various coupling agents to covalently bind to specific ligands 
[17-19]. Finally, the most important is that the silica layer provides magnetic nanoparticles with a surface chemically friendly to biological systems.

Among various chemical synthesis coating methods, the sol-gel process offers several advantages, including good homogeneity, low cost, and high purity.

The electrical nature of the sample-water interface is the result of the hydrolysis of the surface species followed by $\mathrm{pH}$-dependent dissociation of surface hydroxyls. A characteristic property of the sample surface is the condition of surface zero charge, known as zero point of charge (zpc), which is usually determined by some form of acid-base titration technique. Surface characteristics may also be investigated by electrokinetic phenomena, which involve the inter-relation between mechanical and electrical effects at a moving interface. Electrokinetic results are generally expressed in terms of zeta potential, which may be calculated from the electrophoretic mobility of particles through a field with known strength. The term, isoelectric point (iep) refers to conditions under which the zeta potential is zero. The surface potential need not be zero when the zeta potential is zero, particularly in the case of specifically adsorbed ions, hence the zpc and iep need not be the same [20].

In this work, zeta-potential measurements are used to monitor coating efficiency besides its characterization by $\mathrm{X}$-ray diffraction (XRD), and Fourier-transform infrared spectroscopy.

\section{EXPERIMENTAL}

\section{Materials}

Reagent grade $\mathrm{FeCl}_{3} \cdot 6 \mathrm{H}_{2} \mathrm{O}$ and $\mathrm{Na}_{2} \mathrm{SO}_{3}$, ammonium hydroxide, ethyl alcohol, acetone, chloridric acid (Synth), and tetraethyl orthosilicate (TEOS -Aldrich 98\%) were used as purchased.

\section{Iron oxide nanoparticle synthesis}

The method proposed in [21] was used in the preparation of nanoparticulate magnetite. Magnetic particles were synthesized using $15 \mathrm{~mL} \mathrm{FeCl}_{3} \cdot 6 \mathrm{H}_{2} \mathrm{O}\left(2 \mathrm{~mol} . \mathrm{L}^{-1}\right)$ dissolved in $0.25 \mathrm{~mol} . \mathrm{L}^{-1} \mathrm{HCl}, 10 \mathrm{~mL}$ of $\mathrm{Na}_{2} \mathrm{SO}_{3}$ stock solution ( $\left.1 \mathrm{~mol} . \mathrm{L}^{-1}\right)$, and $25.4 \mathrm{~mL}$ of ammonium hydroxide solution diluted to a total volume of $400 \mathrm{~mL}$. The reaction was carried out in 1000-mL 3-necked round bottom flask by bubbling a protective gas (nitrogen) for ensure an inert atmosphere. Just after mixing $\mathrm{Fe}^{3+}$ and $\mathrm{SO}_{3}{ }^{2-}$, the color of the solution changed from light yellow to red and afterwards back to yellow. At that moment, the diluted ammonia solution was poured into the solution quickly under vigorous stirring and a black precipitate was formed. The reaction was continued by stirring for an additional $30 \mathrm{~min}$. The supernatant was discarded and the black precipitate was centrifuged with distilled water. This procedure was repeated five times and then, the precipitate obtained was centrifuged with acetone and subsequently placed in a desiccator and dried at room temperature. Then, the sample was reduced in a Pyrex tube under $\mathrm{H}_{2}$ flowing at $50 \mathrm{~mL}$. $\mathrm{min}^{-1}$ for $2 \mathrm{~h}$ at increasing temperature from 20 to $250^{\circ} \mathrm{C}$ at a rate of $10^{\circ} \mathrm{C} \cdot \mathrm{min}^{-1}$ which was held for a total heating period of $2 \mathrm{~h}$. This sample was labeled Mt.

\section{Silica-coating of iron oxide nanoparticle}

Silica coating was carried out using modified reported methods [22, 23]. Deng e cols. prepared silica-coated magnetite nanoparticles using different types of alcohols, and various volume ratios of ethanol to water $\left(V_{\mathrm{E} / \mathrm{W}}\right)$. The feeding amount of catalyst and TEOS were also varied and the synthesis products were carefully characterized. In our study we used the optimized experimental conditions obtained in those studies. The formulations of each reaction were the same except for the type of catalyst. Typically $0.04 \mathrm{~g}$ of magnetic powder was diluted with $160 \mathrm{~mL}$ ethyl alcohol. This dispersion was homogenized by ultrasonic vibration in water bath for $10 \mathrm{~min}$. Finally, $40 \mathrm{~mL}$ water, $1 \mathrm{~mL}$ TEOS, and either $5 \mathrm{~mL}$ ammonia aqueous $(\mathrm{pH} 10)$ or $5 \mathrm{~mL}$ of acidified ( $\mathrm{HCl}-\mathrm{pH} 1.7)$ aqueous solution were slowly added to this dispersion and stirred for $24 \mathrm{~h}$. At this point, magnetic separation was made with the help of a permanent magnet and the magnetic powder collected alone was thoroughly washed with distilled water six times. These samples were named MtSi-a and MtSi-b, where a and $\mathrm{b}$ denote the acid (pH equal 4.1) and basic media $(\mathrm{pH}$ equal 11.4), respectively. The samples were placed under humidified atmosphere overnight and next treated in dry room atmosphere for $96 \mathrm{~h}$.

\section{Glass synthesis}

A silica glass control sample was prepared for zeta potential study. In this case TEOS was added to an acidified $(\mathrm{HCl}-\mathrm{pH} 1.7)$ aqueous solution, and next added to ethanol in a molar proportion of $\mathrm{H}_{2} \mathrm{O}$ :TEOS: $\mathrm{CH}_{3} \mathrm{CH}_{2} \mathrm{OH}$ of $4: 1: 4$. The solution was magnetically stirred until gelation. The material was placed under humidified atmosphere overnight and next treated in dry atmosphere for $24 \mathrm{~h}$.

\section{Characterization methods}

Sample structure, homogeneity, and the formation of silica-coated magnetite nanoparticles were evaluated by comparison of FTIR spectra of coated and non-coated samples. For these analyses, samples were compacted with $\mathrm{KBr}$ (approximately 1\%) and analyzed in transmission mode in a Perkin Elmer Spectrum GX spectrophotometer. $\mathrm{X}$-ray diffraction measurements were performed in a Rigaku model Geigerflex apparatus using Cuk $\alpha$ radiation from 20 to $80^{\circ}(2 \theta)$ at a scan rate of $4^{\circ} \cdot \mathrm{min}^{-1}$ and silicon as an external standard.

Zeta Potential $(\xi)$ and particle size were determined in a Nano Size ZS apparatus. For zeta potential measurements the ground material was suspended in water and homogenized 
with ultrasound for $15 \mathrm{~min}$. After this time, another suspension was made by adding drops of the previous suspension to an aqueous solution of KCL $10^{-3} \mathrm{~mol} \cdot \mathrm{L}^{-1}$. The $\mathrm{pH}$ of this solution was measured and adjusted with either aqueous $\mathrm{NaOH} 10^{-3}$ mol.L $\mathrm{L}^{-1}$ or $\mathrm{HNO}_{3} 10^{-3}$ mol.L-1 $\xi$ was measured as a $\mathrm{pH}$ function. For particle size measurements, an aqueous suspension of magnetic powders were ultrasonic for $10 \mathrm{~min}$ and next they are left to rest during $30 \mathrm{~min}$.

\section{RESULTS}

\section{Magnetite nanoparticles}

XRD results (Fig. 1a) showed the presence of two phases corresponding to magnetite and elementary iron in sample Mt. The line broadening observed is essentially due to the nanoparticle size effect. The average particle size of this magnetite sample estimated from breadths of reflection 311 in Scherrer equation was $10 \mathrm{~nm}$.

Fig. $2 b$ shows the FTIR spectra of sample Mt. Since magnetite has an inverse spinel-type structure, it shows bands indicating the vibrations $\mathrm{M}_{\mathrm{T}}-\mathrm{O}-\mathrm{M}_{\mathrm{O}}\left(v_{1} \approx 600-550 \mathrm{~cm}^{-1}\right)$,
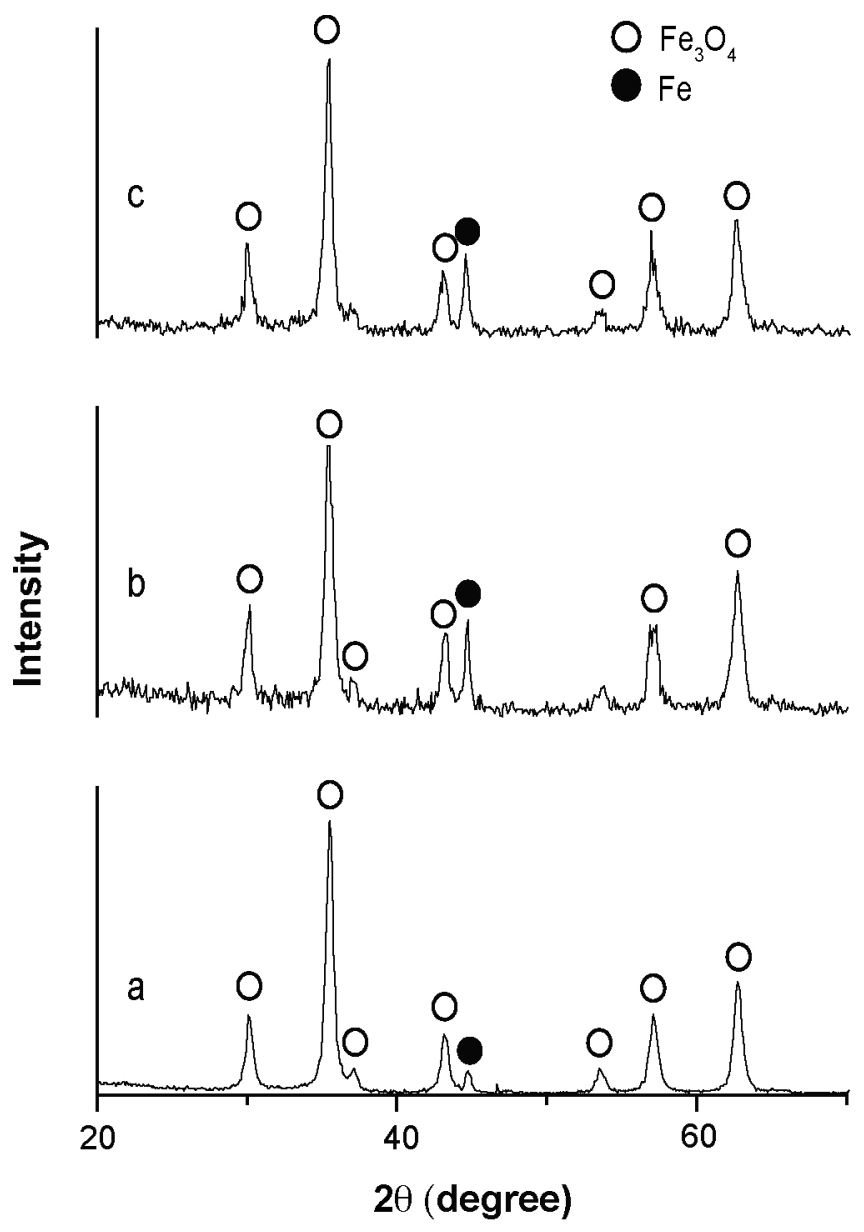

Figure 1: X-ray diffraction patterns of samples: (a) Mt, (b) MtSi-b, and (c) MtSi-a.

[Figura 1: Difratogramas de raios X das amostras Mt (a), MtSi-b (b) e MtSi-a (c).]

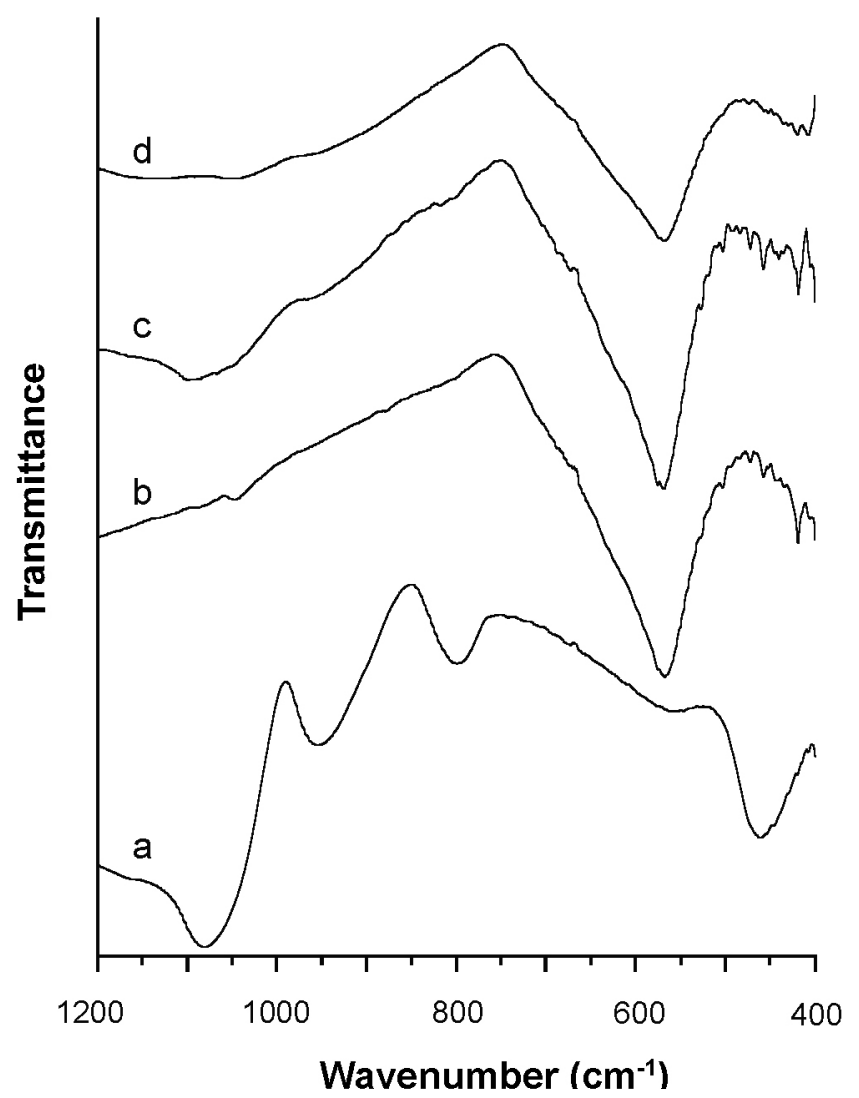

Figure 2: FTIR spectra of (a) glass, (b) Mt, (c) MtSi-b, and (d) MtSi-a.

[Figura 2: Espectro infra-vermelho com transformada de Fourier do vidro (a), Mt (b), MtSi-b (c) e MtSi-a (d).]

$\mathrm{M}_{\mathrm{O}}-\mathrm{O}\left(v_{2} \approx 470 \mathrm{~cm}^{-1}\right)$, and $\mathrm{M}_{\mathrm{T}}-\mathrm{M}_{\mathrm{O}}\left(v_{3} \approx 350-400 \mathrm{~cm}^{-1}\right)$, where $\mathrm{M}_{\mathrm{T}}$ and $\mathrm{M}_{\mathrm{O}}$ correspond to the metal occupying tetrahedral and octahedral positions, respectively [24-26]. Due to instrument limitations, we were unable to observe vibrations type ' $v_{3}$ ', although ' $v_{1}$ '- and ' $v_{2}$ '-type bands were well defined. Table I shows the reported absorbance values of various iron oxides $[27,28]$.

Fig. 3 shows the variation of the zeta potential as a function of $\mathrm{pH}$ solution for sample Mt. The $\mathrm{pH}$ corresponding to the isoelectric point $\left(\mathrm{pH}_{\text {IEP }}\right)$ of this sample is about 5.0.

Table I - IR bands of various iron oxides.

[Tabela I - Bandas da região do infra-vermelho de vários óxidos de ferro.]

\begin{tabular}{cc}
\hline Iron oxide & IR bands $\left(\mathrm{cm}^{-1}\right)$ \\
\hline Magnetite & 590 \\
Maghemite & $630,590,570,450$ \\
Hematite & 540,470 \\
Feroxyhyte & $1110,920,790,670$ \\
Lepidocrocite & $1026,1161,753$ \\
Goethite & 890,797 \\
Akaganeite & 840,640 \\
\hline
\end{tabular}




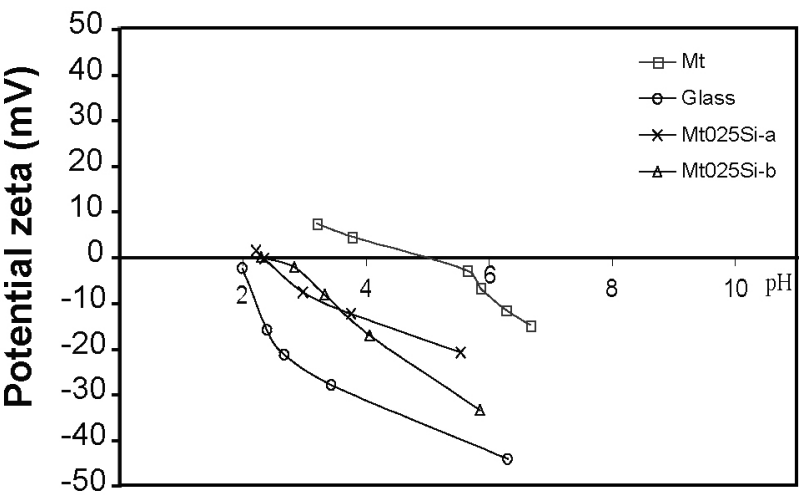

Figure 3: Variation of zeta potential of glass, Mt, MtSi-b, and MtSi-a with $\mathrm{pH}$.

[Figura 3: Potencial zeta de vidro, Mt, MtSi-b e MtSi-a em função do $\mathrm{pH}$.

These results are in a good agreement with data found in the literature [29].

\section{Silica-coated magnetite particles}

Fig. $1 \mathrm{~b}$ and $\mathrm{c}$ shows the X-ray diffraction patterns of silica-coated samples. The spectrum includes $\mathrm{Fe}_{3} \mathrm{O}_{4}$ and some Fe diffraction peaks, and it is very similar to that of non-coated sample as expected.

FTIR spectrum of silica glass control sample (Fig 2a) presented bands at 1080,800 , and $460 \mathrm{~cm}^{-1}$ due to the $\mathrm{Si}$ O-Si bonds [30-32] and a peak at $960 \mathrm{~cm}^{-1}$ associated to Si$\mathrm{OH}$ bond vibrations [33]. Sample MtSi-b (Fig. 2c) presented peaks related to the $\mathrm{Si}-\mathrm{O}-\mathrm{Si}$ bond at $1080 \mathrm{~cm}^{-1}$ and $800 \mathrm{~cm}^{-1}$, besides a peak at $575 \mathrm{~cm}^{-1}$ associated with $\mathrm{Fe}-\mathrm{O}$ bonds. The shoulder at $960 \mathrm{~cm}^{-1}$ present in the FTIR spectrum of this sample is composed of contributions from $\mathrm{Si}-\mathrm{O}-\mathrm{H}$ stretching and $\mathrm{Fe}-\mathrm{O}$ vibrations [34]. As no substantial shifts are observed when coated and non-coated spectra are compared, the formation of Fe-O-Si bonds may not be evoked.

The FTIR spectrum of sample MtSi-a (Fig. 2d) showed a broad band characteristic of Si-O bands at about 1200 to 900 $\mathrm{cm}^{-1}$ and another at $570 \mathrm{~cm}^{-1}$, characteristic of magnetite.

Fig. 3 shows the variation of the zeta potential as a function of solution $\mathrm{pH}$ for samples Mt, MtSi-a, MtSi-b, and for pure silica glass. The $\mathrm{pH}$ corresponding to the isoelectric point $\left(\mathrm{pH}_{\mathrm{IEP}}\right)$ of the Mt sample is about 5.0. Samples MtSi-a and MtSi-b presented a $\mathrm{pH}_{\mathrm{IEP}}$ of 2.3, and the $\mathrm{pH}_{\mathrm{IEP}}$ of pure glass is about 2.0 .

\section{DISCUSSION}

To verify the surface charge effect of magnetite particles, the zeta potential of silica-coated and non-coated particles was measured as a function of the solution $\mathrm{pH}$ (Fig. 3). The $\mathrm{pH}_{\text {iep }}$ of magnetite nanoparticles is about 5.0, while all coated particles showed a $\mathrm{pH}$ dependency similar to that of pure silica. Their $\mathrm{pH}_{\text {IEP }}$ was about 2.3, whilst pure silica has a $\mathrm{pH}_{\text {IEP }}$ equal to 2.0. The observed difference of $\mathrm{pH}_{\text {IEP }}$ in $\mathrm{KCl}$ solution confirms that the coating process was effective since the charge surface properties of magnetic nanoparticles are close to that of pure silica. The nature of the species present in the base and acid catalyst medium coating should be different. Magnetite powders have a $\mathrm{pH}_{\text {iep }}$ equal to 5.0, which means that for coating at $\mathrm{pH} 11.4$, the magnetite presented a negative surface, while that coated at $\mathrm{pH} 4.1$ presented a positive surface. It is expected that at $\mathrm{pH} 11.4 \mathrm{FeO}^{-}$groups predominate over $\mathrm{FeOH}_{2}^{+}$groups on magnetite surface in contrast to that at $\mathrm{pH} 4.1$. However, our results show that coating occurred in both conditions.

Hypotheses of specific interactions between magnetite nanoparticles and silica have been advanced in the literature. Particle dispersability in the silica matrices may result from various types of interactions: covalent, through $\mathrm{Si}-0-\mathrm{Fe}$ bond formation; electrostatic, between negatively charged Si-0 terminal ligands and positively charged groups on the particle surface; or hydrogen-bond interactions between hydration layers of silanol groups and the particle surface [35]. Bruni et al. [36] proposed a model for $\mathrm{Fe}_{2} \mathrm{O}_{3}-\mathrm{SiO}_{2}$ nanocomposites in which iron oxide nanocrystals in silica matrix pores are closer to the matrix surface with the elimination of interconnected water by producing a magnetic interaction between iron (III) and silica ions. The presence of $\mathrm{Si}-\mathrm{O}-\mathrm{Fe}$ bonds in the dried gel strongly indicates an interaction between well isolated $\mathrm{Fe}^{3+}$ ions and the nearest silica matrix. Li et al. [37] observed similar results for $\mathrm{NiFe}_{2} \mathrm{O}_{4}$ nanocrystals dispersed in a silica matrix. IR and EPR spectroscopies were used in those studies to follow the changes. In our study, no extra bands related to $\mathrm{Fe}-\mathrm{O}-\mathrm{Si}$ bonds appeared in Fourier-transform infrared spectra of coated samples. Therefore, if $\mathrm{Fe}^{+3}-\mathrm{Si}$ interaction occurs, it seems to be very faint. In fact, the Bruni model [36] suggests that the $\mathrm{Fe}_{3} \mathrm{O}_{4}$ nanoparticles interact with either the silica matrix or the silanol groups on the surface of the cavities where they are formed. After heating at 300,500 , and $700{ }^{\circ} \mathrm{C}$, the vibration bands due to adsorbed $\mathrm{H}_{2} \mathrm{O}$ molecules and silanol groups were little intense as polycondensation takes place. The Fe-O-Si band $\left(590 \mathrm{~cm}^{-1}\right)$ appears after heating at $700{ }^{\circ} \mathrm{C}$.

\section{CONCLUSION}

Zeta potential measurements showed that magnetite nanoparticles were successfully coated with silica in base- and acid-catalysis synthesis conditions. In both cases, coated magnetite presented almost the same $\mathrm{pH}_{\text {IEP }}$ as that of the pure glass sample. Moreover, the nanoparticles remained magnetic after coating and their particle size decreased about $30 \%$ after coating, probably due to the expected effect of the silica coating preventing nanoparticle agglomeration.

\section{ACKNOWLEDGMENTS}

The authors acknowledge financial support provided by FAPEMIG. 


\section{REFERENCES}

[1] S. Sun, C. B. Murry, D. Welle, L. Folk, A. Moser, Science 287 (2002) 1989.

[2] M. Chen, D. E. Nikles, Nano Lett. 2 (2002) 211.

[3] E. V. Shevchenko, D. V. Talapin, A. L. Rogach, A. Kornowski, M. Haase, H. Weller, J. Am. Chem. Soc. 124 (2002) 11480.

[4] D. K. Kim, Y. Zhang, J. Kehr, T. Klason, B. Bjelke, M. Muhammed, J. Magn. Magn. Mater. 225 (2001) 256.

[5] C. H. Reynolds, N. Annan, K. Beshah, J. H. Huber, S. H. Shaber, R. E. Lenkinski, J. A. Wortman, J. Am. Chem. Soc. 122 (2000) 8940.

[6] A. S. Lubbe, C. Bergemann, H. Riess, F. Schriever, P. Reichardt, K. Possinger, M. Matthias, B. Dorken, F. Herrmann, R. Gurtler, P. Hohenberger, N. Haas, R. Sohr, B. Sander, A. J. Lemke, D. Ohlendorf, W. Huhnt, D. Huhn, Cancer Res. 56 (1996) 4686.

[7] C. Bergemann, D. Muller-Schulte, J. Oster, L. Brassard, A. S. Lubbe, J. Magn. Magn. Mater, 194 (1999) 45.

[8] D. C. F. Chan, D. B. Kirpotin, P. A. Bunn, J. Magn. Magn. Mater. 122 (1993) 374.

[9] A. Jordan, R. Scholz, P. Wust, H. Schirra, T. Schiestel, H. Schmidt, R. Felix, J. Magn. Magn. Mater. 194 (1999) 185.

[10] A. Dyal, K. Loos, M. Noto, S. W. Chang, C. Spagnoli, K. V. P. M. Shafi, A. Ulman, M. Cowman, R. A. Gross, J. Am. Chem. Soc. 125 (2003) 1684.

[11] M. Wakamatsu, N. Takeuchi, S. Ishida, Rep. Asahi Glass Found. 56 (1990) 243.

[12] R. M. Cornell, U. Schwertmann, The Iron Oxides: Structure, Properties, Reactions, Occurrence and Uses, VCH, New York, USA (1996) pp. 28-29.

[13] E. J. W. Verwey, Nature 144 (1939) 327.

[14] S. Santra, R. Tapec, N. Theodoropoulou, J. Dobson, A. Hebard, W. H. Tan, Langmuir 17 (2001) 2900.

[15] H. H. Yang, S. Q. Zhang, X. L. Chen, Z. X. Zhuang, J. G. Xu, X. R. Wang, Anal. Chem. 76 (2004) 1316.

[16] Z. Ma, Y. Guan, H. Liu, J. Magn. Magn. Mater. 301 (2006) 469.

[17] A. P. Philipse, M. P. B. van Bruggen, C. Pathmamanoharan, Langmuir 10 (1994) 92.

[18] Q. Liu, Z. Xu, J. A. Finch, R. Egerton, Chem. Mater.
10 (1998) 3936.

[19] X. Q. Liu, Z. Y. Ma, J. M. Xing, H. Z. Liu, J. Magn. Magn. Mater. 270 (2004) 1.

[20] K. Quast, Miner. Eng. 19 (2006) 582.

[21] S. C. Qu, H. B. Yang, D. W. Ren, S. H. Kan, G. T. Zou, D. M. Li, M. H. Li, J. Colloid Interface Sci. 215 (1999) 190.

[22] Y. H. Deng, C. C. Wang, J. H. Hu, W. L. Yang, S. K. Fu, Colloids Surf. A, Physicochem. Eng. Asp. 262 (2005) 87.

[23] W. Stober, A. Fink, E. Bohn, J. Colloid Interface Sci. 26 (1968) 62.

[24] E. Barrado, F. Prieto, J. Medina, F. A. López, J. Alloys Compd. 335 (2002) 203.

[25] J. L. M. de Vidales, A. López-Delgado, E. Vila, F. A. López, J. Alloys Compd. 287 (1999) 276.

[26] M. Ma, Y. Zhang, W. Yu, H. Y. Shen, H. Q. Zhang, N. Gu, Colloids Surf. A, Physicochem. Eng. Asp. 212 (2003) 219.

[27] R. M. Cornell, The Iron Oxides: Structure, Properties, Reactions, Occurrences and Uses, Wiley, New York, USA, ISBN 3527302743 (2003).

[28] U. Schwertzman, R. M. Cornell, Iron Oxides in the Laboratory-Preparation and Characterization, $\mathrm{VCH}$ Verlagsgesellschaft, Weiden, Germany (1991).

[29] M. Erdemoglu, M. Sarıkaya, J. Colloid Interface Sci. 300 (2006) 795.

[30] A. Bertoluzza, C. Fagnano, M. A. Morelli, V. Gottardi, M. Guglielni, J. Non-Cryst. Solids 48 (1982) 117.

[31] M. C. Matos, L. M. Ilharco, R. M. Almeida, J. NonCryst. Solids 147 (1992) 232.

[32] P. Y. Chu, D. E. Clark, Spectrosc. Lett. 25 (1992) 201.

[33] H. Yoshino, K. Kamiya, H. Nasu, J. Non-Cryst. Solids 126 (1990) 68.

[34] A. Al-bawabe, S.E. Friberg, J. Sjoblom, G. Farrington, J. Disper. Sci. Technol. 19 (1998) 613.

[35] C. Chaneac, E. Tronc, J. P. Jolivet, J. Mater. Chem. 6 (1996) 1905.

[36] S. Bruni, F. Cariati, M. Casu, A. Lai, A. Musinu, G. Piccaluga, S. Solinas, Nanostruct. Mater. 11 (1999) 573.

[37] G. S. Li, L. P. Li, R. L. Smith, H. Inomata, J. Mol. Struct. 560 (2001) 87.

(Rec. 12/12/2008, Ac. 13/02/2009) 